\title{
History of Medical Treatment Unknown
}

National Cancer Institute

\section{Source}

National Cancer Institute. History of Medical Treatment Unknown. NCI Thesaurus. Code C160181.

The history of medical treatments is unknown. 